\title{
CARDIOVASCULAR RESPONSE OF ATHLETES UNDER DIFFERENT TRAINING CONDITIONS
}

\author{
RESPOSTA CARDIOVASCULARDE ATLETAS EM DIFERENTES CONDIÇÕES DE TREINAMENTO \\ RESPUESTA CARDIOVASCULARDE ATLETAS EN DIFERENTES CONDICIONES DE ENTRENAMIENTO
}

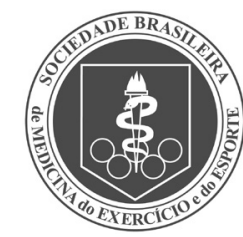

Original Article

ARtigo ORIGINAL

Artículo Original
Jiyan Chen ${ }^{1}$ (D)

(Physical Education Professional)

1. Ningxia Normal University,

Guyuan, Ningxia, China.

\section{Correspondence:}

Jiyan Chen

Guyuan, Ningxia, China. 756000.

JiyanChen3@163.com

\begin{abstract}
Introduction: Improving cardiovascular function is one of the main training goals of many sports. Objective: To understand the characteristics of the cardiovascular response of athletes under different training conditions. Methods: Thirty male basketball students were enrolled. The subjects were divided into A and B groups according to their years of training, with 15 students in each group. Exercise fatigue tests were performed, starting at a low intensity and gradually increasing the load to a relatively high degree of fatigue. Results: The RMSSD value was $42.82 \pm 31.41 \mathrm{~ms}$ in group $A$ and $46.48 \pm 35.26 \mathrm{~ms}$ in group $B$ under a low fatigue state. The LF/HF value of the athletes in group $A$ was $2.86 \pm 1.47$ and the LF/HF value of the athletes in group $B$ was $2.94 \pm 1.68$. The RMSSD value was $40.78 \pm 31.17 \mathrm{~ms}$ and $32.37 \pm 36.42 \mathrm{~ms}$ for groups $A$ and $B$, respectively, under a high fatigue state. Conclusions: Athletes with more years of training can mobilize more cardiac reserves to meet the increase in exercise load in a fatigue state and have better autonomic nervous regulation in the process of reaching a higher degree of fatigue state. Level of evidence Il; Therapeutic studies - investigation of treatment results.
\end{abstract}

Keywords: Cardiovascular; Fatigue; Health personnel.

\section{RESUMO}

Introdução: Melhorar a função cardiovascular éum dos principais objetivos do treinamento em muitos esportes. Objetivo: Compreender as características da resposta cardiovascular de atletas em diferentes condições de treino. Métodos: Trinta estudantes do sexo masculino ejogadores de basquete foram inscritos. Os participantes foram divididos em grupos $A$ e B, de acordo com os anos de treinamento, com 15 estudantes em cada grupo. Foram realizados testes de fadiga por exercício, que no início foi de baixa intensidade e aumentou gradualmente até um grau relativamente alto. Resultados: O valor de RMSSD foi de 42,82 $\pm 31,41$ ms no grupo A e de 46,48 $\pm 35,26$ ms no grupo B em estado de fadiga baixa. O valor de LF/HF dos atletas do grupo A foi 2,86 $\pm 1,47$ e o dos atletas do grupo B foi 2,94 $\pm 1,68$. $O$ valor RMSSD foi de $40,78 \pm 31,17 \mathrm{~ms}$ e 32,37 $\pm 36,42 \mathrm{~ms}$ para os grupos $A$ e $B$, respectivamente, em estado de fadiga elevada. Conclusões: Os atletas com mais anos de treinamento podem mobilizar mais reservas cardíacas para atender ao aumento da carga de exercício em estado de fadiga e ter melhor regulação do sistema nervoso autônomo no processo de atingir um grau maior de estado de fadiga. Nível de Evidência ll; Estudos terapêuticos - Investigação dos resultados do tratamento.

Descritores: Cardiovascular; Fadiga; Pessoal de saúde.

\section{RESUMEN}

Introducción: La mejora de la función cardiovascular es uno de los principales objetivos del entrenamiento en muchos deportes. Objetivo: Comprender las características de la respuesta cardiovascular de atletas en diferentes condiciones de entrenamiento. Métodos: Se inscribieron 30 estudiantes del sexo masculino y jugadores de baloncesto. Los participantes se dividieron en los grupos Ay B según los años de entrenamiento, formando 15 estudiantes en cada grupo. Se realizaron pruebas de fatiga por ejercicio, que al principio fueron de baja intensidad y fueron aumentando gradualmente hasta un grado relativamente alto. Resultados: El valor de RMSSD fue de 42,82 $\pm 31,41$ ms en el grupo A y de 46,48 $\pm 35,26$ ms en el grupo B en estado de baja fatiga. El valor de LF/HF de los atletas del grupo A fue de 2,86 $\pm 1,47$ y el de los at letas del grupo B fue de 2,94 $\pm 1,68$. El valor de RMSSD fue de 40,78 $\pm 31,17$ ms y 32,37 $\pm 36,42$ ms para los grupos A y B, respectivamente, en estado de fatiga elevada. Conclusiones: Los atletas con más años de entrenamiento pueden movilizar más reservas cardiacas para hacer frente al aumento de la carga de ejercicio en estado de fatiga y presentan una mejor regulación del sistema nervioso autónomo en el proceso de alcanzar un mayor grado de estado de fatiga. Nivel de Evidencia ll; Estudios terapéuticos - Investigación de los resultados del tratamiento.

Descriptores: Cardiovascular; Fatiga; Personal de salud. 


\section{INTRODUCTION}

Subaltitude hypoxia training is one of the ways to improve the athletes' physical working ability and stimulate their physical movement function.' According to the training monitoring data, the effects of targeted training on athletes'body function system state in the sub-plateau and plain areas can be evaluated. ${ }^{2}$ The training degree of athletes can be objectively evaluated by monitoring biochemical indicators, monitoring the state of cardiovascular system (the method of analyzing cardiac rhythm variation), testing the body's working ability under graded loads, and evaluating the body's energy supply effect and maximum energy supply possibility. ${ }^{3}$ To master the characteristics of the adaptive changes of athletes' heart function to long-term training and the stress changes to different loads, it has very important theoretical and practical significance for sports material selection, evaluation of training effects and improvement of training methods ${ }^{4}$ To address this research problem, Visnes $\mathrm{H}$ et al pointed out in a comparative study of heart rate variability in basketball and football college athletes that, long-term systematic training can effectively improve cardiac autonomic nerve regulation by taking into account various indicators in time and frequency domains, it is manifested as decreased heart rate in quiet state, prolonged R-R interval, and improved vagus nerve function. ${ }^{5}$ Jin-young A N et al believed that long-term endurance training can increase the oxidative phosphorylation ability of muscle, increase the density of mitochondria, aerobic enzyme activity increased, capillaries and myoglobin increased. The changes in physiological adaptation mentioned above will result in the increase of ATP provided by mitochondrial aerobic oxidation. ${ }^{6}$

\section{METHOD}

\section{Basic Information}

Select 30 male students majoring in basketball from a sports university. Aged between 18 and 25, in good health, normal diet and lifestyle were maintained during the training, fifteen of them were trained for 1-2 years, and the other 15 were trained for $4-5$ years. The subjects were divided into a and B groups according to their training years, with 15 students in each group.

\section{Experimental design}

The experiment was conducted when the subjects had no intense competition or training in the past 3 days. Before the fatigue test was established, the subjects were given RSSOOpolar table to carry out the exercise fatigue test, the experiment started at low intensity and gradually increased the load, in the experiment, the corresponding speed, slope and interval time of running platform were set by Bruce scheme. Starting from the first stage, the platform automatically moves to the next stage every 2 minutes. A relatively low degree of fatigue was achieved when subjects reached $85 \%$ of their maximum heart rate and exercised at this load for 2 minutes (in order to obtain stable vascular indicators). At this point, subjects'finger blood is taken immediately to measure their blood lactic acid concentration and blood pressure, in order to ensure the accuracy of the data, the process should be done quickly to minimize the error of the data measurement. At lower intensity, subjects' heart rate values and heart rate variability values were read on a Polar scale. The fatigue test was then continued after $85 \%$ of the maximum heart rate was reached and exercise continued at this load for 20 minutes (or subjects were unable to continue exercise), at this point a relatively high degree of fatigue is achieved. At this time, the heart rate and heart rate variability of subjects were read by RSSOOpolar Table. Subjects' finger blood was then promptly taken to measure their haemorrhagic acid concentration and their blood pressure. The heart rate and blood pressure of the subjects were measured again $3 \mathrm{~min}$ after exercise to observe their exercise recovery?

\section{RESULTS}

\section{Comparison of heart rate variability data between the two} groups under low degree of fatigue

As shown in Figure 1 and 2, RMSSD value of group $A$ athletes at low fatigue state is $42.82 \pm 31.41 \mathrm{~ms}$, the RMSSD value of group $B$ athletes was $46.48 \pm 35.26 \mathrm{~ms}$ when they reached low fatigue state. According to independent sample $T$ test, the comparison of RMSSD value of group $A$ in the state of low fatigue with that of group B athletes in the state of low fatigue is as follows: $P=0.694$, $P$ values $>0.05$. This indicates that the RMSSD value of group $A$ under low fatigue state has no significant difference with that of group $B$ under low fatigue state. ${ }^{8}$

The LF/HF value of the athletes in group A was $2.86 \pm 1.47$, and the $\mathrm{LF} / \mathrm{HF}$ value of the athletes in group $B$ was $2.94 \pm 1.68$. According to the independent sample $T$ test, the comparison of $\mathrm{LF} / \mathrm{HF}$ value of group $\mathrm{A}$ in the state of low fatigue with the LF/HF value of group $B$ in the state of low fatigue is as follows: $P=0.492$, $P$ values $>0.05$. It indicates that there is no significant difference between the LF/HF values of the athletes in group $A$ and group $B$ when they reach the lower fatigue state.

\section{Comparison of HEART rate variability data between the two groups under high fatigue state}

As shown in Figure 3 and 4, the RMSSD value of athletes in group A and group $B$ was $40.78 \pm 31.17 \mathrm{~ms}$ and $32.37 \pm 36.42 \mathrm{~ms}$ when they reached high fatigue state. After independent sample T test, the comparison of RMSSD value of group $A$ at $A$ high fatigue state and that of group $B$ at A high fatigue state can be obtained as follows: $P=0.037, P$ values $<0.05$. This indicates that RMSSD value of group A in high fatigue state is significantly different from that of group B in high fatigue state. ${ }^{9}$

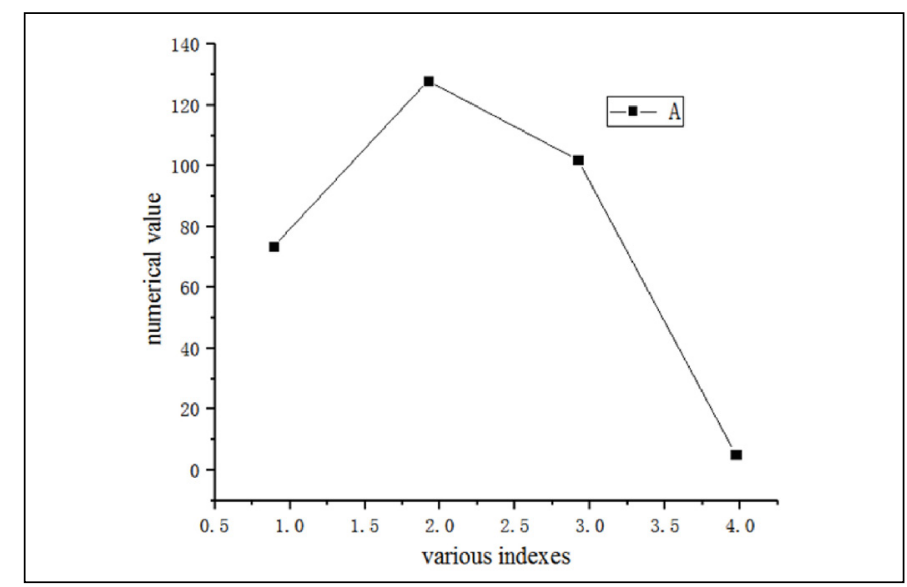

Figure 1. A group under low fatigue state indicators.

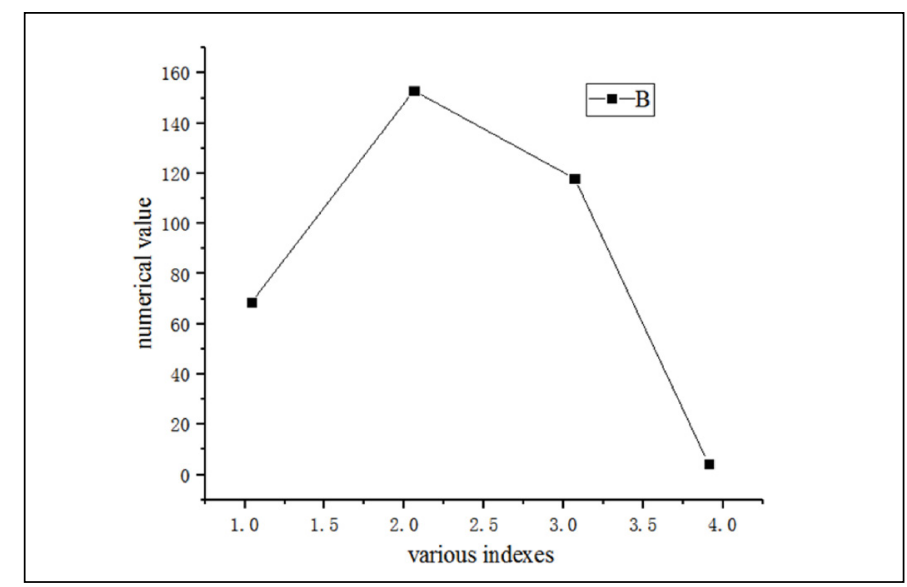

Figure 2. B Group indicators under low fatigue state.. 


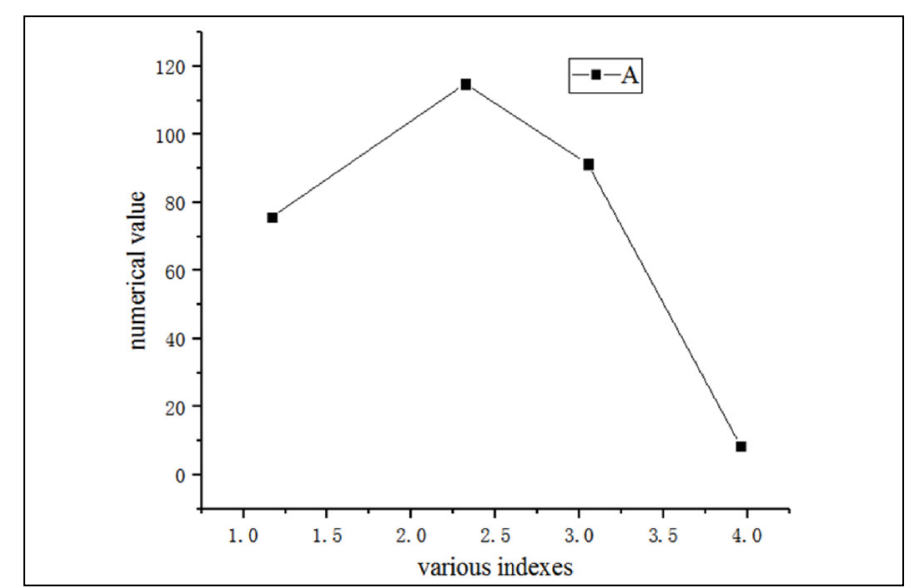

Figure 3. A group under high fatigue state indicators.

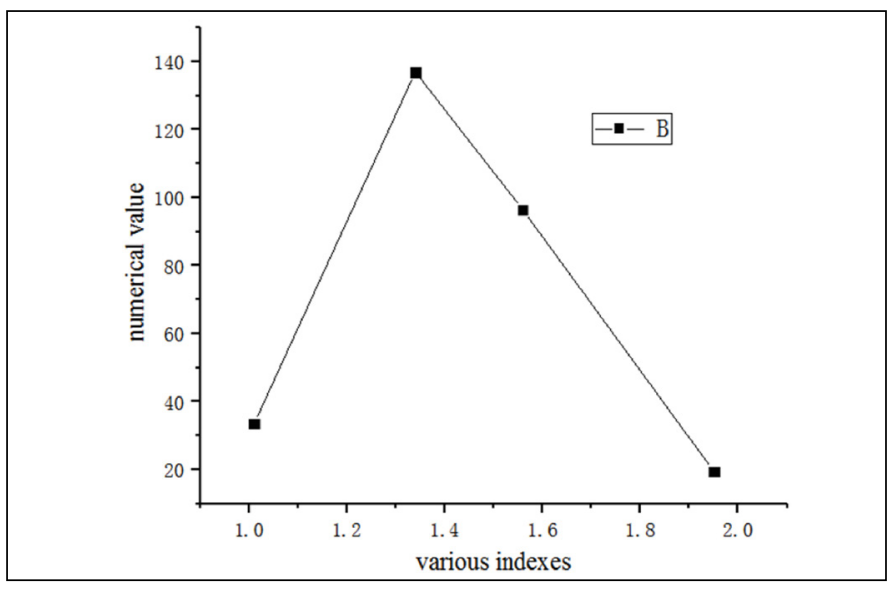

Figure 4. B group indicators under high fatigue state.

The LF/HF value of the athletes in group A was 2.96 \pm 1.79 , and that of the athletes in group B was 3.22 \pm 1.85 . According to the independent sample T test, the comparison of the LF/HF value of group A at A high fatigue state and the LF/HF value of group $B$ at $A$ high fatigue state is as follows: $P=0.044$, $P$ values $<0.05$. It indicates that the LF/HF value of group $A$ in high fatigue state is significantly different from that of group B in high fatigue state. ${ }^{10}$

\section{DISCUSSION}

Comparison of HEART rate variability indexes between the two groups in the process of achieving low fatigue state

There were no significant differences in heart rate variability except LF between group A and group B. There was no significant difference in the heart rate variability (RMSSD) between group A and group A during the process of reaching A lower degree of fatigue, before exercise, RMSSD in group A was significantly lower than that in group B, indicating that parasympathetic nerve activity in group $B$ was significantly lower after exercise than before exercise. The LF index of heart rate variability in group
A was significantly lower than that in group $B$, and there was no significant difference in LF index between the two groups before exercise, the results showed that sympathetic nerve activity increased significantly in group $B$ during the process of low fatigue state. There was no significant difference in HF between the two groups, before exercise, the HF index of group A was significantly lower than that of group B, indicating that after exercise, the vagal nerve activity level of group B was much lower than that before exercise. In conclusion, when exercise reached the fatigue state, the sympathetic nerve activity increased and the parasympathetic and vagal nerve activity decreased in group $B$ were greater than that in group $A$, the results showed that the degree of autonomic nerve regulation in group $B$ was more obvious in the process of exercise fatigue.

\section{Comparison of HEART rate variability indexes between the two groups in the process of high fatigue state}

There were significant differences in heart rate variability except LF between group A and group B. In the process of reaching A high degree of fatigue, the heart rate variability index RMSSD of group A was significantly higher than that of group $B$, the results showed that the parasympathetic activity of group $B$ decreased more obviously after the exercise reached the fatigue state. There was no significant difference in LF index between the two groups, indicating that the sympathetic nerve activity of the subjects in the two groups increased to the same extent when they continued to exercise after fatigue state. HF index of heart rate variability in group $A$ was significantly lower than that in group $B$, indicating that vagal nerve activity in group $B$ was higher at this time, however, the heart rate variability index LF/HF in group A was significantly lower than that in group B, indicating that under the balanced regulation of sympathetic nerve and vagus nerve, the proportion of sympathetic nerve activity in autonomic nerve regulation in group $B$ was higher than that in group $B$. These results indicated that group $B$ had better autonomic nerve regulation in the process of achieving a higher degree of fatigue.

\section{CONCLUSION}

Athletes with longer training years can mobilize more cardiac reserves to meet the increase of exercise load in fatigue state when the fatigue state is high, and have better autonomic nervous regulation in the process of reaching a higher degree of fatigue state. In the future, cardiovascular response of athletes under fatigue state will be measured before systematic training, so as to minimize the fatigue movement of athletes during training and competition, and ensure the safety of athletes.

\section{ACKNOWLEDGMENT}

The study was partly supported by the First-class Discipline Construction (Pedagogy Discipline) funding project of Ningxia Higher Education Institutions, Project No.:NXYLXK2017B11.

The author declare no potential conflict of interest related to this article

\section{REFERENCES}

1. Suppiah HT, Low CY, Chia M. Effects of sports training on sleep characteristics of Asian adolescent athletes. Biol Rhythm Res. 2015;46(4):523-36.

2. EE Hibberd, Laudner K, Berkoff DJ, Kucera KL, Yu B, Myers JB. Comparison of Upper Extremity Physical Characteristics Between Adolescent Competitive Swimmers and Nonoverhead Athletes. J Athl Train. 2016;51 (1):65.

3. Sugimoto D, Alentorn-Geli E, Mendiguchía J, Samuelsson K, Karlsson J, Myer GD. Biomechanical and Neuromuscular Characteristics of Male Athletes: Implications for the Development of Anterior Cruciate Ligament Injury Prevention Programs. Sports Med. 2015;45(6):809-22.

4. Visnes $H$, Tegnander A, Bahr R. Ultrasound characteristics of the patellar and quadriceps tendons among young elite athletes. Scand J Med Sci Sports. 2015;25(2):205-15.

5. Jin-Young AN, Seo JB, Choi JH, Lee JH, Kim H. Evaluation of Characteristics of Coke Degradation after Reaction in Different Conditions. ISIJ Int. 2016;56(2):226-32.
6. Jin-Young AN, Seo JB, Choi JH, Lee JH, Kim H. Evaluation of Characteristics of Coke Degradation after Reaction in Different Conditions. ISIJ Int. 2016:56(2):226-32.

7. J Lévesque, Rivaz H, Rizk A, Frenette S, Boily M, Fortin M. Lumbar Multifidus Muscle Characteristics, Body Composition, and Injury in University Rugby Players. J Athl Train. 2020;55(10):1116-23.

8. Roelofs EJ, AE Smith-Ryan, Trexler ET, Hirsch KR. Seasonal Effects on Body Composition, Muscle Characteristics, and Performance of Collegiate Swimmers and Divers. J Athl Train. 2017;52(1):45-50.

9. Gervasi M, Sisti D, Amatori S, Andreazza M, Benelli P, Sestili P, et al. Muscular viscoelastic characteristics of athletes participating in the European Master Indoor Athletics Championship. Eur J Appl Physiol. 2017;117(8):1739-46.

10. Runciman P, Derman W, Ferreira S, Albertus-Kajee Y, Tucker R. A Descriptive Comparison of Sprint Cycling Performance and Neuromuscular Characteristics in Able-Bodied Athletes and Paralympic Athletes with Cerebral Palsy. Am J Phys Med Rehabil. 2015;94(1):28-37. 